\title{
Behavioral engagement and disaffection in school activities: exploring a model of motivational facilitators and performance outcomes
}

\author{
Antonio González ${ }^{1 *}$, Paola-Verónica Paoloni² ${ }^{2}$ Danilo Donolo ${ }^{2}$ and Cristina Rinaudo ${ }^{2}$ \\ 1 Universidad de Vigo (Spain). \\ 2 Universidad Nacional de Río Cuarto, Córdoba (Argentina).
}

\begin{abstract}
Título: Compromiso conductual y desafección con las actividades escolares: explorando un modelo de facilitadores motivacionales y resultados de rendimiento.

Resumen: Investigaciones previas han mostrado que el control percibido, el valor de la tarea, el compromiso conductual y la desafección son determinantes personales del rendimiento académico. Sin embargo, pocas investigaciones han examinado simultáneamente estos constructos en educación secundaria. El presente estudio analizó las relaciones estructurales entre estas variables y el papel del compromiso y la desafección como mediadores de los efectos del control y el valor sobre el rendimiento. Los participantes fueron 446 estudiantes (51.3\% chicas) con edades comprendidas entre 12 y 16 años que asistían a seis colegios de educación secundaria obligatoria (de $7^{\circ}$ a $10^{\circ}$ cursos; de $1^{\circ}$ a $4^{\circ}$ de ESO). Las variables se evaluaron a lo largo de nueve meses. Los resultados de los modelos de ecuaciones estructurales confirmaron las hipótesis: el control y el valor predijeron significativamente el compromiso, la desafección y el rendimiento; el compromiso y la desafección predijeron el rendimiento y mediaron parcialmente los efectos del control y el valor sobre el rendimiento. Se concluye discutiendo las implicaciones para la teoría y la práctica psicoeducativa.

Palabras clave: Educación Secundaria; control percibido; valor de la tarea; compromiso académico; desafección; rendimiento académico.
\end{abstract}

\section{Introduction}

Motivation is a key factor influencing and predicting success in academic settings. Different models seeking to explain academic motivation underscore the impact of two constructs: task value, concerned with the importance assigned to an activity and the interest shown in performing it; and perceived control, understood as perceptions on one's own ability to influence academic performance.

An academic outcome, derived from motivation, is referred to as engagement with academic tasks, a multidimensional construct consisting of three basic components: behavioral (e.g., effort), emotional (e.g., enjoyment), and cognitive (e.g., deep learning strategies). At the opposite end of the continuum of engagement we find disaffection, a concept characterized by reduced effort, negative emotions, and surface learning strategies.

This study begins by analyzing how current psychological research has characterized the terms task value, perceived control, behavioral engagement, and behavioral disaffection. This review of the terminology will provide the theoretical framework for analyzing the relationships between these variables in relation to academic performance in a sample of secondary school students.

* Dirección para correspondencia [Correspondence address]:

Antonio González. Universidad de Vigo. Facultad de Ciencias de la Educación. As Lagoas. 32004. Ourense (Spain). E-mail: aglez@uvigo.es
Abstract: Previous research has shown that perceived control, task value, behavioral engagement and disaffection are personal determinants of academic performance. However, little research has simultaneously examined these constructs in secondary education. The present study analyzed the structural relationships between these variables and the role of engagement and disaffection as mediators of control and value on performance. Participants were 446 students (51.3\% girls) ranging in age from 12 to 16 years attending six Spanish compulsory secondary schools (from 7 th to 10 th grades). The variables were assessed over a nine-month period. Structural equation models results confirmed the hypotheses: control and value significantly predicted engagement, disaffection, and performance; engagement and disaffection predicted performance and partially mediated the effects from control and value on performance. Implications for psychoeducational theory and practice are discussed.

Key words: Secondary education; perceived control; task value; academic engagement; disaffection; academic performance.

\section{Task value and perceived control}

First, the criteria for defining and operationalizing the two motivational variables evaluated in this study were reviewed i.e., subjective task value and perceived academic control

As for the first of these motivational constructs, subjective task value is, in addition to expectancy, the main variable in the motivational model of Eccles and Wigfield (2002; Wigfield, Tonks, \& Klauda, 2009). These authors distinguish several components of subjective task value, two of which are particularly noteworthy: attainment value or the importance of doing well in a task in terms of one's selfschema; and interest or intrinsic value, the inherent pleasure one gets from engaging in an activity; both aspects are frequently intensely correlated. The other components of subjective task value are utility value and cost.

In their model, Eccles and Wigfield (2002) claim subjective task value is a strong predictor of performance in an array of academic tasks. Likewise, other studies have found a positive relationship between task value and academic performance in different academic subjects (Archambault, Eccles, \& Vida, 2010; Durik, Vida, \& Eccles, 2006; Hulleman, Godes, Hendricks, \& Harackiewicz, 2010; Johnson \& Sinatra, 2013; Pekrun, Goetz, Daniels, Stupnisky, \& Perry, 2010).

The second motivational variable was perceived control. Control constructs are widely reported to play a crucial role in several motivational theories such as outcome expectancy, perceived self-efficacy, expectancy of success, locus of control, and perception of capacity (Skinner, 1996). Control is 
particularly relevant for attribution theory since controllability is a basic causal dimension explaining the motivational, emotional, and behavioral consequences of causal beliefs (Thomson \& Schlehofer, 2008).

Control constructs were also positively related to several self-regulatory processes, such as monitoring, self-regulation, executive functioning, metacognition (Roebers, Cimeli, Röthlisberger, \& Neuenschwander, 2012), and with cognitive and metacognitive management skills (Sastre-Riva, 2013). All of these skills, strategies, and processes enable and improve students' adequate learning and academic outcomes.

Moreover, control constructs have implications for one's aspirations and expectations (Thompson \& Schlehofer, 2008): individuals with high perceived control generally have greater aspiration levels and select harder tasks than those low in perceived control. Likewise, positive relationships have been found between control constructs and perfectionism or perfectionistic thinking (Pyryt, 2007), specially when perfectionism is self-oriented, i.e., characterized by setting excessively high standards and having a perfectionist motivation for oneself (Stoeber, Feast, \& Hayward, 2009). Thus, self-oriented perfectionism was positively correlated to motivational constructs such as achievement motivation (Fletcher \& Neumeister, 2012), self-efficacy (Bong, Arum, Arum, \& Sung-il, 2014; Stoeber, Hutchfield, \& Wood, 2009), mastery goals (Bong et al., 2014), and intrinsic motivation (Stoeber et al., 2009).

Of the modalities of control, perceived control has been the primary focus of extensive research, and is defined in terms of one's own perceived ability to significantly determine or modify events in the surrounding environment (Skinner, 1996). Perceived academic control is a domain-specific form of perceived control in classroom settings and describes a student's beliefs regarding his/her ability to predict and influence academic outcomes (Perry, Hladkyj, Pekrun, \& Pelletier, 2001). Perceived academic control positively correlated with academic performance in university students (Hall, Perry, Chipperfield, Clifton, \& Haynes, 2006; Stupnisky, Perry, Hall, \& Guay, 2012), and elementary school students (Furrer \& Skinner, 2003).

\section{Behavioral engagement and disaffection}

In recent years, the analysis of student engagement has been approached from different perspectives that have highlighted several components (González González, 2010; Lawson \& Lawson, 2013; Martin, 2008; Reeve \& Tseng, 2011; Skinner, Kinderman, Connell, \& Wellborn, 2009a). In this multidimensional construct three classical components have been identified: behavioral (e.g., persistence), emotional (e.g., enthusiasm), and cognitive (e.g., use of learning strategies).

Behavioral engagement has been defined as interactions with the academic setting that are active, goal driven, flexible, constructive, and persistent (Hughes, Wu, \& West, 2011; Martin, 2008; Skinner \& Pitzer, 2012). According to these authors, some indicators of behavioral engagement in academic contexts are planning, effort, on-task attention, concentration, hard work, persistence, time expended, attendance, voluntary participation, task involvement, and follow classroom rules and norms. Frequently, this behavior was accompanied by emotions such as enthusiasm, interest, enjoyment, satisfaction, pride, and vitality.

Conversely, at the other pole of the scale to engagement we find burnout (Salanova, Schaufeli, Martínez, \& Bresó, 2010), disengagement (Martin, Anderson, Bobis, Way, \& Vellar, 2012) or disaffection (Elmore \& Huebner, 2010; García, Casal, Merino, \& Sánchez, 2013; Skinner, Furrer, Marchand, \& Kinderman, 2008; Skinner, Kinderman, \& Furrer, 2009b). Though there are several types of disaffected students, this construct was closely aligned to passivity, amotivation, alienation, and helplessness. Behavioral disaffection was typically operationalized in terms of lack of participation and effort, distraction, passivity, procrastination, selfhandicapping, and lacking persistence (Elmore \& Huebner, 2010; Skinner et al., 2009a). This behavior was often associated to frustration, discouragement, resignation, dejection, sadness, and apathy.

Affective or emotional engagement includes positive and negative reactions towards teachers, classmates, academic tasks and activities, and the schools itself. These are often subdivided into two categories i.e., affective responses in the classroom, such as interest, enjoyment, happiness or anxiety during academic activities; and students' feelings of identification and relatedness to their school peers, teachers, and the school overall (Lawson \& Lawson, 2013).

Finally, cognitive engagement focuses on the analysis of the students' psychological investment of mental energy required for undertaking academic tasks. Some activities and strategies indicative of cognitive engagement are thinking profoundly about complex concepts, asking questions to clarify ideas or concepts they fail to understand, reading more than the assigned material, and using cognitive, selfregulating, and metacognitive strategies (Lawson \& Lawson, 2013).

As for the relationship between engagement and performance, academic achievement was positively associated to effort, persistence, and engagement (Chouinard, Karsenti, \& Roy, 2007; Greene, Miller, Crowson, Duke, \& Akey, 2004; Liem, Lau, \& Nie, 2008; Liem \& Martin, 2011; Miñano, Gilar, \& Castejón, 2012). On the contrary, some indexes of burnout and disaffection were negatively correlated to academic achievement (Salanova, Martínez, Bresó, Llorens, \& Grau, 2005).

\section{Relating engagement with value and control}

Several studies have examined the relationships between revised motivational variables (intrinsic value and perceived control), and an array of indicators and modalities of engagement and disaffection. 
Thus, effort and persistence were positively correlated to importance and intrinsic value in students at different levels of education: university (Jang, 2008; Pekrun et al., 2010), secondary school (Hong, Peng, \& Rowell, 2012; Martin et al., 2012), and elementary school, high school, and university (Martin, 2009; Pekrun et al., 2010). Furthermore, task value negatively correlated with some indicators of disaffection such as attention deficits (Pekrun et al., 2010), taskdisengagement (Liem et al., 2008), and self-handicapping (Martin, 2009).

Moreover, perceived academic control positively correlated with behavioral engagement in elementary education (Furrer \& Skinner, 2003; Skinner et al., 2008; Skinner et al., 2009b), and to effort and persistence in higher education (Pekrun et al., 2010). Behavioral disaffection negatively correlated with perceived academic control in elementary education (Skinner et al., 2008). On the other hand, uncertain control negatively correlated with persistence and school engagement, and positively correlated with self-handicapping and disengagement (Martin, 2009; Martin \& Marsh, 2008).

Additionally, recent studies have applied structural equation modeling to examine the role of components of engagement as mediators between motivational variables and academic achievement. Thus, there was a significant indirect effect of perceived ability, self-efficacy, achievement goals, and perceived instrumentality on achievement through cognitive engagement (Greene et al., 2004). Task-engagement mediated the effects of peer relationships on performance (Liem \& Martin, 2011). Effort and learning strategies were significant mediators between goal orientations and final academic achievement (Miñano et al., 2012). Finally, engagement and burnout mediated the relations between motivation and performance (Salanova et al., 2005, 2010).

\section{Aims of the study}

Little research has simultaneously examined control, value, engagement, disaffection, and performance. Moreover, to our knowledge, there is no mention in the literature of any research analyzing these variables simultaneously in secondary schools. In this context, the purpose of the current study was to examine the association of task value and perceived control to behavioral engagement, disaffection, and performance in compulsory secondary education bearing in mind the recommendations of Skinner et al. (2009a) who consider it of especial importance to analyze disaffection in contexts from which individuals cannot voluntarily exit, such as school during compulsory education.

The theoretical framework for this study is based on the model described by researchers such as Reeve (2012) and Skinner and Pitzer (2012). Sharing common points of view, these authors posit that diverse indicators of engagement (e.g., behavioral engagement and disaffection) act as mediators between facilitators or enablers of engagement (i.e., task value end perceived control) and learning outcomes (i.e., academic performance). Based on this model and empirical evidence outlined above, we expected to find the relationships depicted in Figure 1.

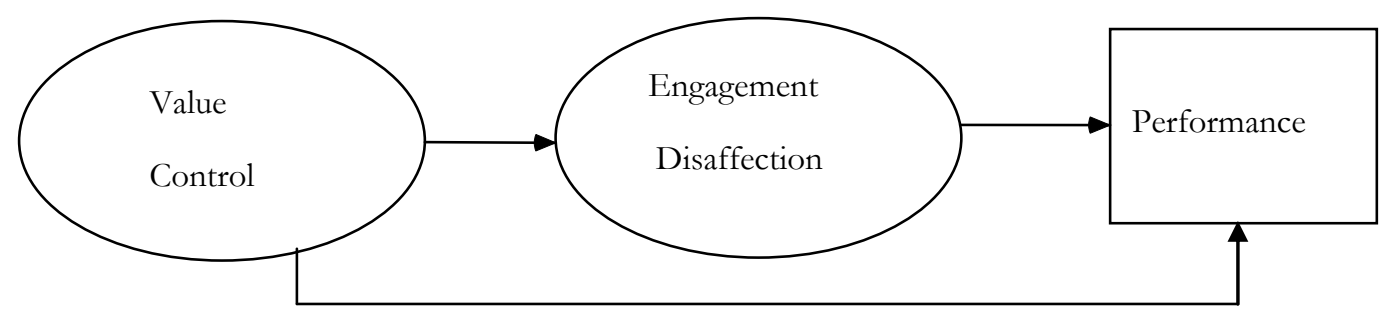

Figure 1. Hypothesized structural mediational model.

Therefore, the following general hypotheses were formulated: (a) Task value and perceived control would positively predict behavioral engagement and academic performance, and negatively behavioral disaffection; (b) Academic performance would be positively predicted by behavioral engagement and negatively predicted by behavioral disaffection; (c) The significant association of task value and perceived control to performance would be mediated by behavioral engagement and disaffection.

\section{Method}

\section{Participants}

The sample consisted of 446 students (51.3\% girls) aged 12 to 16 years (mean age $=13.91$ years; $S D=1.19$ years) who were studying compulsory secondary education (from 7 th to 10 th grades). The students belonged to 13 classrooms in 6 state schools in two cities in the North West of Spain.

The school board provided access to both the students' and their parents' data with the latters' prior informed consent. According to the data, approximately $7 \%$ of all the students were on remedial teaching programmes at school, particularly in the subjects of mathematics and Spanish language, and $14 \%$ of students had repeated a grade. In terms 
of origin, $91 \%$ of students were born in Spain, 3.5\% were South American, 2.5\% from other EU countries, 2\% African, and 1\% from Asia or Oceania. As for the parents' academic status, $21 \%$ were university graduates, $27 \%$ had undertaken further education ( $12^{\circ}$ grade), and $52 \%$ had completed or failed to finish Compulsory Secondary Education $\left(10^{\circ}\right.$ grade $)$.The data regarding the origin of students and the academic status of parents were similar to the general school population in Spain for the year 2009 (INEE, 2011).

\section{Measures}

Task value .A subscale of the Perceived Task Value Scale (Eccles \& Wigfield, 1995) was administered consisting of four items, two for each component of value: intrinsic value or interest, as "In general, I find working on class assignments: very boring (1), very interesting (7)"; and attainment value or importance, as "Compared to your other activities, how important is it to you to be good at academic activities: not at all important (1), very important (7)". Eccles and Wigfield (1995) applied both of these subscales to secondary students obtaining satisfactory reliability indices ( $\alpha=.76$ for intrinsic value and $\alpha=.70$ for attainment value); moreover, a strong correlation was observed between both subscales $(r=.78)$. Notwithstanding, these authors (see also Eccles, O’Neill, \& Wigfield, 2005) found the reliability index for the extrinsic utility value subscale was low $(\alpha=.62)$; hence, this subscale was not applied in this study. The poor reliability of this subscale has been highlighted by Husman, Derryberry, Crowson, and Lomax (2004).

Perceived control. Perceived control was evaluated using the Academic Control Scale of Perry et al. (2001). This instrument consists of eight items for reporting the student's opinion on a range of factors influencing academic performance in a general academic context (e.g., "I have a great deal of control over my academic performance in my courses" or "The more effort I put into my courses, the better I do in them"). The students scored the items on a scale ranging from 1 ( $I$ totally disagree) to 5 (I totally agree). Four items underwent recoding in accordance with Perry et al. (2001), where a high score in each of the items and in the total indicates greater perceived control. This questionnaire has been extensively used (Hall et al., 2006; Pekrun et al., 2010; Perry et al., 2001; Stupnisky et al., 2012) with good reliability indices ( $\alpha$ values between .72 and .85$)$.

Engagement and disaffection. We applied the Behavioral Engagement and Disaffection with Learning Subscales: Student Report, proposed by Skinner et al. (2008). The subscale of behavioral engagement consisted of five items that evaluated the students' attention, effort, and persistence while initiating and participating in learning activities (e.g., "When I'm in class, I participate in class discussions" or "In class, I work as hard as I can"). The behavioral disaffection subscale consisting of five items evaluated the presence of behaviors indicative of poor engagement in learning (e.g., "When I'm in class, I just act like I'm working" or "When I'm in class, I think about other things"). Students scored their behavior on a scale varying between 1 (not at all true for me) to 4 (very true for me). Skinner et al. $(2008,2009 b)$ confirmed satisfactory reliability indices of these scales ( $\alpha=.72$ for behavioral engagement and $\alpha=$ 71 for behavioral disaffection).

The Spanish version of these scales (value, control, engagement, and disaffection) was designed using the crosscultural scale translation technique. The process involves three stages: a) the original scale was translated from English to Spanish in accordance with the parallel back-translation procedure (Brislin 1986) i.e., a bilingual translator translated the original English text into Spanish, and another translated it back into English; b) a team of two translators and two expert lecturers on motivation selected the items that matched the initial meaning as well as writing the instructions and setting the format of the scale which was identical to the English version; c) finally, the Spanish version of the scales was applied to 10 secondary students to evaluate the clearness and adequacy of each item.

Academic performance. The student's mean final grade was used to assess academic performance. In the Spanish school system, grades range from 1 (very deficient) to 10 (excellent). The pass mark was a score $\geq 5$.

\section{Procedure}

Students completed a series of questionnaires over a nine-month period. The motivational scales were completed in October, the behavioral engagement and disaffection scales in May, and the teachers reported the mean final grades in June. Students completed their questionnaires in their classrooms, and none refused to fill in the questionnaires. One researcher and a teacher were present during data collection. The students had approximately 10 minutes to complete each questionnaire. Written authorization was obtained from parents or legal guardians and all students freely volunteered to participate in the study. Teachers and students were informed of the aims of the research, reminded of the importance of providing sincere responses, and guaranteed their data would remain anonymous and confidential. To ensure confidentiality, each student was assigned a code that was to be written on each scale.

\section{Outline of data analyses}

Statistical analysis initially determined the reliability coefficients (Cronbach's alpha), the descriptive statistics, and the correlations between variables using the SPSS.22 statistical package. Confirmatory factorial analysis (CFA) of the scales was then undertaken to confirm the fit of the measurement model using the AMOS 22 software (Arbuckle, 2013). Finally, a series of structural equation analyses (SEM) was performed to contrast the proposed mediational model. In both analyses (CFA and SEM), the model fit was evaluated by the following indices (Byrne, 2010): the $\chi^{2}$ statistic, the most 
common measure though it is quite sensitive to sample size; the $\chi^{2} / d f$ indicator, the adjusted goodness of fit index (AGFI), the comparative fit index (CFI), the root mean square error of approximation (RMSEA), and the standardized root mean square residual (SRMR).

SEM was used to assess assumptions on the relationships between variables. These analyses offer several advantages over other methods (Tomarken \& Waller, 2005) i.e., they allow for the analysis of statistically non-normal data; enable theoretical knowledge to be introduced into model specification; can test phenomena assessing multiple endogenous and exogenous variables; use latent variables, each of which is evaluated by multiple indicators; and they take into account the role of mediating variables and not just the direct effects of one variable on another.

According to $\mathrm{Wu}$ and Zumbo (2008), the most frequent procedure in mediation analysis consists of four stages. Step 1 is to determine if the independent variable predicts the dependent variable. Step 2 analyzes if the independent variable is related to the mediator. Step 3 examines the effect of the mediator on the dependent variable to determine if it is predicted by both the independent variable and the mediator. Finally, Step 4 compares the direct effects of stages 1 and 3 to test if this direct effect is significantly reduced or disappears.

\section{Results}

Table 1 shows the mean for engagement was higher than the mean for disaffection $\left(t_{(445)}=8.448 ; p<.001\right)$. Task value, control, engagement, and performance were positively correlated, and negatively with disaffection.

Table 1. Descriptive statistics, alphas, and correlations of measured variables.

\begin{tabular}{lcccccccr}
\hline Variables & Mean & SD & $\alpha$ & 1 & 2 & 3 & 4 & 5 \\
\hline 1. Value & 4.21 & 1.1 & .80 & - & & & & \\
2. Control & 3.17 & .61 & .78 & .18 & - & & & \\
3 Engagement & 2.71 & .53 & .75 & .30 & .25 & - & & \\
4. Disaffection & 2.36 & .56 & .71 & -.25 & -.31 & -.29 & - & \\
5. Performance & 7.01 & 1.6 & - & .38 & .33 & .46 & -.42 & - \\
\hline Note: all of the correlations were significant $(p<.01)$. & & & &
\end{tabular}

A multivariate analysis of variance (MANOVA) was performed to detect grade differences. The values obtained for, Wilks' $\lambda=.972, \mathrm{~F}(5,438)=.833, p>.05, \eta^{2}=.009$, indicated there were no significant grade differences in any of the assessed variables. All alpha values were above the recommended minimum $(\alpha \geq .71)$.

\section{Measurement model}

In order to assess the relationship between measured items and latent variables, a confirmatory factor analysis was performed. The latent variables were task value, perceived control, behavioral engagement, and disaffection. The indicators were four parcels on perceived control, four items of task value, and five items on engagement and disaffection. The items of the perceived control scale were grouped for factorial and structural equation analysis using the procedure employed with the same scale by Pekrun et al. (2010) to calculate the mean of two correlated items with a similar significance. In line with the recommendations of Byrne (2010), parceling was implemented to improve model parsimony by decreasing the number of parameters estimated. This grouping gave rise to four parcels, and their corresponding means were used as indicators.

All of the indicators obtained indices of asymmetry and kurtosis below $|1.96|$, confirming the univariate normality assumption (Byrne, 2010). No atypical multivariate observations (outliers) were found. Nevertheless, Mardia's multivariate kurtosis coefficient (5.03) exceeded the critical ratio (c.r. $=1.97)$. Thus, in order to determine the influence of nonnormality on the estimators, two types of analysis were performed (Arbuckle, 2008; Byrne, 2010): one for the original sample using the maximum likelihood method; the other for the 500 bootstrap samples, using the maximum likelihood method; a 95\% confidence interval was set to evaluate corrected bias. According to Byrne (2010), the key principle underlining the bootstrapping procedure is that it enables the researcher to simulate repeated subsamples from an original database. This resampling method allows for assessing the stability of parameter estimates, reporting their values with a greater degree of accuracy, and addressing situations where the statistical assumptions of multivariate normality may not hold. The comparison of the results obtained by both methods revealed no differences. Therefore, we now proceed to review the results of the analysis performed on the original sample. No re-specifications of the initial model were carried out.

The measurement model fit the observed data well, $\chi^{2}(d f$ $=129, \mathrm{~N}=446)=153.9, p<.05 ; \chi^{2} / d f=1.19 ; \mathrm{AGFI}=.95$; $\mathrm{CFI}=.98$; RMSEA $=.021$; SRMR $=.034$. The standardized factor loadings were satisfactory $(\beta \geq .52 ; p<.01)$, indicating the measurement model was appropriate.

\section{Structural model}

Thereafter, three structural equation analyses were performed to corroborate the initial hypotheses (as presented in Fig. 1) regarding the mediation between variables. As the multivariate kurtosis coefficient was above the critical ratio for the full mediational model, both types of analysis applied in CFA were undertaken. The comparison of the results obtained by both methods revealed no differences. No respecifications of the initial models were carried out. Figure 2 displays the full mediational model. 


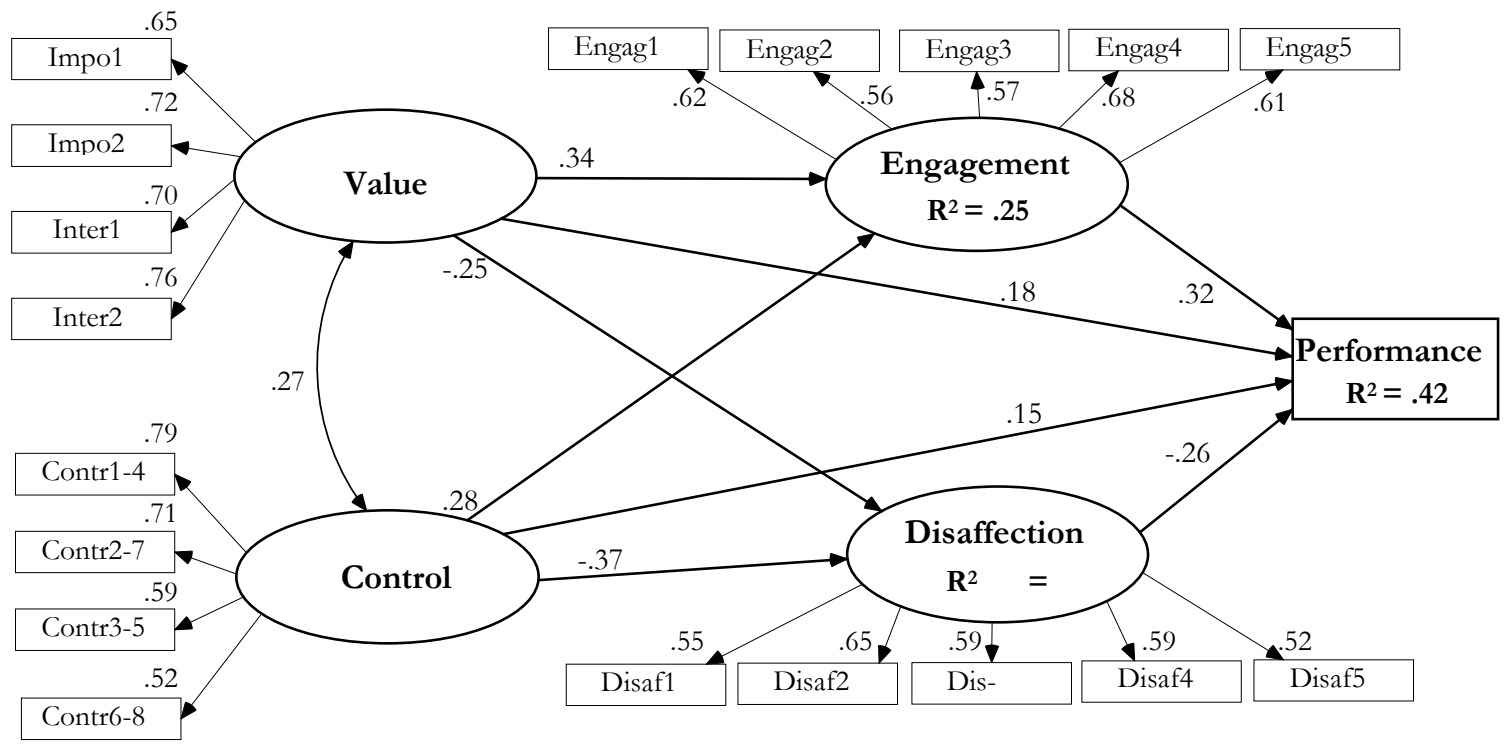

Figure 2. The final structural model. Note: All standardized paths were significant at $p<.01$.

First (Step 1), preliminary structural equation model analysis was undertaken in which task value and perceived control were entered as predictors of academic performance. This analysis showed that the model fit the data, $\chi^{2}(d f=25$; $\mathrm{N}=446)=31.04, p>.05 ; \chi^{2} / d f=1.36 ; \mathrm{AGFI}=.98 ; \mathrm{CFI}=$ .99 ; RMSEA $=.025$; SRMR $=.024$. Academic performance was positively associated to task value $(\beta=.35, p<.01)$ and to perceived control $(\beta=.33, p<.01)$. Task value and perceived control explained $28 \%$ of the variance of academic performance.

Second (Step 2), the nexus between task value and perceived control as predictors, and the dependent variables engagement and disaffection were assessed. The indices revealed the model once again fit the data well, $\chi^{2}(d f=130, \mathrm{~N}$ $=446)=162.5, p<.02 ; \chi^{2} / d f=1.25 ; \mathrm{AGFI}=.95 ; \mathrm{CFI}=$ .98 ; $\mathrm{RMSEA}=.024 ; \mathrm{SRMR}=.040$. Task value and perceived control positively predicted engagement $(\beta=.34, p<$ .01 and $\beta=.28, p<.01)$, and negatively predicted disaffection $(\beta=-.25, p<.01$ and $\beta=-.37, p<.01)$. On the whole, the variance explained by task value and perceived control was $23.8 \%$ for engagement and $24.2 \%$ for disaffection.

The full mediational model (Step 3) showed a very good fit to the data, $\chi^{2}(d f=144, \mathrm{~N}=446)=185.02, p<.01 ; \chi^{2} / d f$ $=1.28$; AGFI $=.94 ; \mathrm{CFI}=.98 ; \mathrm{RMSEA}=.025 ; \mathrm{SRMR}=$ .040 . Task value and control negatively predicted disaffection and were positive predictors of engagement. Performance was positively predicted by engagement, and negatively by disaffection.
Table 2. Direct, indirect, and total effects of motivation on academic performance.

\begin{tabular}{lcccc}
\hline Motivational & Direct effects & \multicolumn{2}{c}{ Indirect effects $\left(^{1}\right)$} & \multirow{2}{*}{$\begin{array}{c}\text { Total } \\
\text { variable }\end{array}$} \\
\cline { 3 - 4 } & $(p)$ & Sum $(p)$ & Intervals & effects \\
\hline Value & $.179(.001)$ & $.173(.006)$ & $.110, .220$ & .351 \\
Control & $.150(.007)$ & $.186(.003)$ & $.104, .227$ & .334 \\
\hline
\end{tabular}

Note. (1) The probability associated to each sum of standardized indirect effects and their respective confidence intervals were estimated using the biascorrected confidence interval bootstrap test of AMOS 22 (confidence level $=95 \%$; samples $=500$ ).

Finally (Step 4), the data obtained from the direct effects in Step 1 were compared to the direct effects in Step 3. As shown in Table 2, the sum of indirect effects, through behavioral engagement and disaffection, was significant for task value $(.173, p<.006)$ and perceived control $(.186, p<$ $.003)$. After including the mediators in the model, the direct effects of task value and control on performance fell sharply: the initial effect of task value on performance $(\beta=.351)$ fell to a final value of $\beta=.179$ with the inclusion of mediators; for perceived control the value dropped from an initial $\beta=$ .334 to a final $\beta=.150$. Notwithstanding, regardless of the sharp falls, the final direct effect was significant for both value and control. These results indicated a partial mediation of task value and control on academic performance through engagement and disaffection. Together, value, control, engagement, and disaffection explained $42 \%$ of the variance of academic performance.

\section{Discussion}

Though perceived control and task value have been extensively reported in the literature, their relationships to behavioral engagement, disaffection, and performance in second- 
ary education has received little attention. In this study, all of the scales applied showed satisfactory reliability indices. Furthermore, the hypothesized relationships were confirmed. No significant differences were found for grade in any of the variables under analysis.

As hypothesized, compulsory secondary students who perceived the academic tasks as more interesting and important reported more behavioral engagement and lower disaffection; as expected, these students achieved higher final mean grades. Analogously, those students who exhibited high levels of perceived control on their academic performance reported lower levels of disaffection and higher levels of engagement and academic performance. Furthermore, students who were more actively engaged in completing classroom tasks, and expressed less disaffection obtained higher grades.

The effects of task value and perceived control on academic performance were partially mediated by behavioral engagement and disaffection. As hypothesized, students who highly valued academic tasks and considered their personal performance to be under their own control exhibited greater engagement with school tasks, and were protected against behavioral disaffection in the classroom. It is worth noting that each of these two behavioral characteristics positively predicted high academic performance; and jointly, both constituted a mediator that partially explained the positive and intense effects of task value and perceived control on academic performance.

\section{Relating findings to previous studies}

Skinner (1996) forecasted that, when people perceive that they have a high degree of control, they exert effort, try hard, and persist in the face of failures. In this same line, Eccles and Wang (2012) assert that the ultimate goal of the expectancy-value model was to predict the intensity of task engagement and performance at school, and they hypothesized that task value would be a proximal precursor of engagement. The findings of this study corroborated these forecasts as well as confirming and contributing to previous research on elementary (Furrer \& Skinner, 2003), secondary (Durik et al., 2006), and college students (Hall et al., 2006; Stupnisky et al., 2012). Task value was the best positive predictor of engagement whereas perceived control was the biggest negative predictor of disaffection. Jointly analyzed with structural equation models, value and control explained a significant proportion of variance in engagement, disaffection, and academic performance in compulsory secondary students.

Moreover, this study focused on attention, participation, effort, and persistence that are some of the basic indicators of behavioral engagement (Jang, 2008; Martin, 2008; Reeve \& Tseng, 2011; Skinner et al., 2008). In addition, most of these authors have underscored the need to examine these indicators in relation to disaffection, the opposite pole to engagement. To our knowledge, this is the first study to use a bipolar scale, as proposed by Skinner et al. (2008), to assess and analyze separately behavioral engagement and disaffection in secondary students. Skinner et al. (2009a) recommended academic disengagement should be explored in greater depth in compulsory education. Moreover, the PISA 2009 Report (INEE, 2010; OECD, 2010) has stressed the importance of developing and assessing individual behavioral engagement in reading, math, and science activities during this stage of education. The findings of the present study support the fundamental role assigned to behavioral engagement and disaffection and corroborated the theoretical mediational model in which engagement and disaffection bridge students' motivation to academic achievement (Reeve, 2012; Skinner and Pitzer, 2012).

Furthermore, these results agree with previous studies that found engagement mediated the relations between motivational constructs and academic achievement (Greene et al., 2004; Liem \& Martin, 2011; Miñano et al., 2012). Each of the two behavioral poles under study i.e., engagement and disaffection, had its own distinctive motivational antecedents and its own differential outcomes. Notwithstanding, in the present study the mediating role of engagement and disaffection was partial. As Reeve (2012) has pointed out, this may be due to the fact that this study assessed only behavioral engagement and disaffection instead of analyzing multiple components of engagement, as was the case of Reeve and Tseng (2011).

\section{Limitations and future research}

The findings of the current study should be interpreted with caution given the following limitations that will spur the direction for future research. First, save the performance data, all other data were self-reported, which may raise the risk of method bias. Although personal motivation (Chouinard et al., 2007; Eccles \& Wigfield, 1995; Perry et al., 2001) and engagement (Liem \& Martin, 2010; Martin et al., 2012), are typically assessed by self-report measures, it is instructive to perform studies that examine motivation and engagement dimensions using data derived from additional sources, such as teachers (Hughes \& Kwok, 2006; Hughes et al., 2011; Skinner et al. 2008, 2009a) or trained observers (Jang, 2008).

In terms of measures, this study did not evaluate utility value; in the future, it would be interesting to analyze this component of task value (Chouinard et al., 2007; Hulleman et al., 2010) and other closely aligned concepts such as instrumentality, future consequences or future time orientation (Greene et al., 2004; Husman et al., 2004).

This study focused on behavioral engagement and disaffection, but other components should also be considered such as emotional engagement (Pekrun \& LinnenbrinkGarcía, 2012) or cognitive engagement (Cleary \& Zimmerman, 2012) along with other indicators of disengagement such as emotional disaffection and procrastination (Skinner et al., 2008) or self-handicapping (Martin, 2008). The combined analysis of the multiple facets of engagement and dis- 
affection would shed light on whether any of these variables totally mediate the impact of motivation on performance, as suggested by Reeve (2012).

In terms of design, our findings would be enriched by assessing the reciprocal relationships between motivation, engagement, and performance throughout several academic years, in line with Archambault et al. (2010), Durik et al. (2006) or Linnenbrink-García, Rogat, and Kosley (2011), and would allow us to explore what Skinner and Pitzer (2012) refer to as "cycles of engagement and disaffection".

Finally, bearing in mind the intense relationships between perfectionism and different motivational concepts (Bong et al., 2014; Fletcher \& Neumeister, 2012; Stoeber et al., 2008, 2009), further research is required to explore (a) how perfectionism is related to task value and perceived control, and (b) the degree to which it conditions each modality of engagement and disaffection (behavioral, cognitive, and emotional).

\section{Implications for practice}

Despite these limitations, the current findings provide empirical support to school psychologists, teachers, and families struggling daily to support and enhance adolescent's motivation, engagement, and achievement in their schools.

Firstly, as Pianta, Hamre, and Allen (2012) have noted, classroom is one of the most proximate and potentially powerful settings for influencing children and youth. Hence, the number of programs designed to promote student motivation and engagement in the classroom in line with the findings of the present study. Some interventions were designed to promote highly valued tasks in classroom settings by encouraging students to explore the relevance of what they were learning (Hulleman et al., 2010), involving students personally in experiments or simulations, and emphasizing mastery and learning goals much more than performance goals (Wigfield et al., 2009). Other authors have focused on attributional retraining procedures, a controlenhancing intervention based on Weiner's theory (Hall et al., 2006): having set the tasks requirements in relation to the student's ability to undertake a task, he/she is encouraged to

\section{References}

Arbuckle, J. (2013). AMOS 22. User's Guide. Chicago, IL: SmallWaters Corporation.

Archambault, I., Eccles, J., \& Vida, M. (2010). Ability self-concepts and subjective value in literacy: Joint trajectories from grades 1 through 12 . Journal of Educational Psychology, 102, 804-816. http://dx.doi.org/10.1037/.a00221075.

Bempechat, J., \& Shernoff, D. (2012). Parental influences on achievement motivation and student engagement. In S. Christenson, A. Reschly, \& C. Wylie (Eds.), Handbook of research on student engagement (pp. 315-342). New York: Springer. http://dx.doi.org/10.1007/978-1-4614-20187_15.

Bong, M., Arum, H., Arum, K, \& Sung-il, K. (2014). Perfectionism and motivation of adolescents in academic contexts. Journal of Educational Psychology, 106(3), 711-721. http://dx.doi.org/10.1037/a0035836. attribute failure to controllable causes such as the use of inadequate strategies or lacking the effort needed, in place of immutable causes such as limited academic ability or low intelligence.

On the other hand, as Reeve (2012) highlights, academic engagement is important because it is a relative malleable student characteristic. Likewise, Pianta et al. (2012) assert that the nature and quality of interactions between teachers and children are fundamental to understand student engagement. To promote engagement and reduce disaffection during learning activities, some of the instructional strategies include providing a rationale (a verbal explanation as to why putting effort) during those lessons that teachers expect students might find uninteresting (Jang, 2008); laying less emphasis on performance goal practices, such as give special privileges to best students or display their work as an example (Hughes et al., 2011); and giving students a developmentally calibrated sense of autonomy, control, competence, choice, and structure (Pianta et al., 2012). Of particular importance are some multidimensional educational intervention programs, as proposed by Martin (2008) that focus on motivational variables (e.g., control, value or mastery orientation), and engagement (e.g., planning, persistence or disengagement) in order to integrate theories, research, and practice on motivation and engagement.

Second, as Bempechat and Shernoff (2012) point out, parents are their children's first and primary guides through their schooling experience, and research in education has consistently reported the fundamental role of the family in fostering motivation and engagement. Thus, there is an intense association between parents' self-reported academic values and the students' academic values through parent involvement in the academic activities of their children (Gniewosz \& Noack, 2012). This and other similar results position parental involvement as a primary protective factor against student disaffection (Bempechat \& Shernoff, 2012; Raftery, Grolnick, \& Flamm, 2012). Furthermore, Raftery et al. (2012) recommend parents foster engagement by encouraging their children's autonomous problem-solving, taking their perspectives, and providing resources that facilitate children's competence.

Brislin, R. (1986). The wording and translation of research instruments. In W. Lonner \& J. Berry (Eds.), Field methods in cross-cultural research (pp. 137-164). Beverly Hills, CA: Sage.

Byrne, B. (2010). Structural equation modeling with AMOS. Basic concepts, applications, and programming (2nd ed.). New York, NY: Routledge.

Chouinard, R., Karsenti, T., \& Roy, N. (2007). Relations among competence beliefs, utility value, achievement goals, and effort in mathematics. British Journal of Educational Psychology, 77, 501-517. http:/ /dx.doi.org/10.1348/000709906X133589.

Cleary, T., \& Zimmerman, B. (2012). A cyclical self-regulatory account of student engagement: Theoretical foundations and applications. In S. Christenson, A. Reschly, \& C. Wylie (Eds.), Handbook of research on student engagement (pp. 237-257). New York, NY: Springer. http://dx.doi.org/10.1007/978-1-4614-2018-7_11. 
Cole, J., Bergin, D., \& Whittaker, T. (2008). Predicting student achievement for low stakes tests with effort and task value. Contemporary Educational Psychology, 33, 609-624. http://dx.doi.org/10.1016/jedpsych.2007.10.002

Durik, A., Vida, M., \& Eccles, J. (2006). Task value and ability beliefs as predictors of high school literacy choices: A developmental analysis. Journal of Educational Psychology, 98, 382-393. http://dx.doi.org/10.1037/00220663.98.2.382.

Eccles, J. S., O’Neill, S. A., \& Wigfield, A. (2005). Ability self-perceptions and subjective task values in adolescents and children. In K. A. Moore \& L. H. Lippman (Eds.), What do children need to flourish? Conceptualizing and measuring indicators of positive development (pp. 237-249). New York, NY: Springer. http://dx.doi.org/10.1007/0-387-23823-9_15.

Eccles, J., \& Wang, M. (2012). So what is student engagement anyway? In S. Christenson, A. Reschly, \& C. Wylie (Eds.), Handbook of research on student engagement (pp. 133-145). New York, NY: Springer. http://dx.doi.org/10.1007/978-1-4614-2018-7_6.

Eccles, J., \& Wigfield, A. (1995). In the mind of the actor: The structure of adolescents' achievement task values and expectancy-related beliefs. Personality and Social Psychology Bulletin, 21, 215-225. http://dx.doi.org/10.1177/0146167295213003.

Eccles, J., \& Wigfield, A. (2002). Motivational beliefs, values, and goals. Annual Review of Psychology, 53, 109-132. http://dx.doi.org/10.1146/annurev.psych.53.100901.135153.

Elmore, G., \& Huebner, S. (2010). Adolescents' satisfaction with school experiences: Relationships with demographics, attachment relationships, and school engagement behavior. Psychology in the Schools, 47, 525-537. http://dx.doi.org/10.1002/pits.20488.

Extremera, N., Durán, A. \& Rey, L. (2007). Inteligencia emocional y su relación con los niveles de burnout, engagement y estrés en estudiantes universitarios. Revista de Educación, 342, 239-256.

Fletcher, K., \& Neumeister, K. (2012). Research on perfectionism and achievement motivation: Implications for gifted students. Psychology in the Schools, 49(7), 668-677. http://dx.doi.org/10.1002/pits.21623

Furrer, C., \& Skinner, E. (2003). Sense of relatedness as a factor in children's academic engagement and performance. Journal of Educational Psychology, 95, 148-162. http://dx.doi.org/10.1037/a0028089

García, M., Casal, J., Merino, R., \& Sánchez, A. (2013). Itinerarios de abandono escolar y transiciones tras la enseñanza secundaria obligatoria. Revista de Educación, 361, 65-94. http://dx.doi.org/10.4438/1988-592XRE-2011-361-135.

Gniewosz, B., \& Noack, P. (2012). What you see is what you get: The role of early adolescents' perceptions in the intergenerational transmission of academic values. Contemporary Educational Psychology, 37, 70-79. http://dx.doi.org/10.1016/j.cedpsych.2011.10.002.

González González, M. (2010). El alumno ante la escuela y su propio aprendizaje: algunas líneas de investigación en torno al concepto de implicación. Revista Iberoamericana sobre Calidad, Eficacia y Cambio en Educación. 8, 11-31.

Greene, B., Miller, R., Crowson, M., Duke, B., \& Akey, K. (2004). Predicting high school students' cognitive engagement and achievement: Contributions of classroom perceptions and motivation. Contemporary Educational Psychology, $29, \quad 462-482$. http://dx.doi.org/10.1016/j.cedpsych.2004.01.006.

Hall, N., Perry, R., Chipperfield, J., Clifton, R., \& Haynes, T. (2006). Enhancing primary and secondary control in achievement settings through writing-based attributional retraining. Journal of Social and Clinical Psychology, 4, 361-391. http://dx.doi.org/10.1521/jscp.2006.25.4.361.

Hong, E., Peng, Y., \& Rowell, L. (2012). Homework self-regulation: Grade, gender, and achievement-level differences. Contemporary Educational Psychology, 19, 269-275. http://dx.doi.org/10.1016/j.lindif.2008.11.009

Hughes, J., \& Kwok, O. (2006). Classroom engagement mediates the effect of teacher-student support on elementary students' peer acceptance: A prospective analysis. Journal of School Psychology, 43, 465-480. http://dx.doi.org/10.1016/j.jsp.2005.10.001

Hughes, J., Wu, W., \& West, S. (2011). Teacher performance goal practices and elementary students' behavioral engagement: A developmental perspective. Journal of School Psychology, 49, 1-23. http://dx.doi.org/10.1016/j.jsp.2010.09.003.

Hulleman, Ch., Godes, O., Hendricks, B., \& Harackiewicz, J. (2010). Enhancing interest and performance with a utility value intervention. Jour- nal of Educational Psychology, 102, 880-895. http://dx.doi.org/10.1037/a0019506

Husman, J., Derryberry, W., Crowson, H., \& Lomax, R. (2004). Instrumentality, task-value, and intrinsic motivation: Making sense of their independent interdependence. Contemporary Educational Psychology, 29, 63-76. http://dx. doi.org/10.1016/S0361-476X(03)00019-5.

INEE (2010). PIS A 2009. Programa para la evaluación internacional de los alumnos OCDE. Informe español. Madrid: Ministerio de Educación.

INEE (2011). Panorama de la educación. Indicadores de la OCDE. Informe español. Madrid: Ministerio de Educación.

Jang, H. (2008). Supporting students' motivation, engagement, and learning during an uninteresting activity. Journal of Educational Psychology, 100, 798811. . http://dx.doi.org/10.1037/a0028089.

Johnson, M. L., \& Sinatra, G. M. (2013). Use of task-value instructional inductions for facilitating engagement and conceptual change. Contemporary Educational Psychology, 38, 51-63. http://dx.doi.org/10.1016/j.cedpsych.2012.09.003

Lawson, M., \& Lawson, H. (2013). New conceptual frameworks for student engagement research, policy, and practice. Review of Educational Research, 83 (3), 432-479. http://dx.doi.org/10.3102/0034654313480891.

Liem, A., Lau, S., \& Nie, Y. (2008). The role of self-efficacy, task value, and achievement goals in predicting learning strategies, task disengagement, peer relationship, and achievement outcomes. Contemporary Educational Psychology, 33, 486-512. http://dx.doi.org/10.1016/j.cedpsych.2007.08.001.

Liem, A., \& Martin, A. (2011). Peer relationships and adolescents' academic and non academic outcomes: Same-sex and opposite-sex peer effects and the mediating role of school engagement. British Journal of Educational Psychology, 81, 183-206. http://dx.doi.org/10.1111/j.20448279.2010.02013.x.

Linnenbrink-García, L., Rogat, T., \& Kosley, K. (2011). Affect and engagement during group instruction. Contemporary Educational Psychology, 36, 13-24. http://dx.doi.org/10.1016/j.cedpsych.2010.09.001.

Martin, A. (2008). Enhancing student motivation and engagement: The effects of a multidimensional intervention. Contemporary Educational Psychology, 33, 239-269. http://dx.doi.org/10.1016/j.cedpsych.2006.11.003.

Martin, A. (2009). Motivation and engagement across the academic life span: A developmental construct validity study of elementary school, high school, and university/college students. Educational and Psychological Measurement, 69 ,

794-824. http://dx.doi.org/10.1177/0013164409332214.

Martin, A. Anderson, J., Bobis, Way, J., \& Vellar, R. (2012). Switching on and switching off in mathematics: An ecological study of future intent and disengagement among middle school students. Journal of Educational Psychology, 104, 1-18. . http://dx.doi.org/10.1037/a0025988.

Martin, A., \& Marsh, H. (2008). Academic buoyancy: Towards an understanding of students' everyday academic resilience. Journal of School Psychology, 46, 53-83. http://dx.doi.org/10.1016/j.jsp.2007.01.002.

Miñano, P., Gilar, R. \& Castejón, J. L. (2012). A structural model of cognitive-motivational variables as explanatory factors of academic achievement in Spanish language and mathematics. Anales de Psicología, 28, 4554. http://hdl.handle.net/10045/22527.

OECD (2010). PISA 2009 results: What students know and can do. Student performance in reading, mathematics and science (Volume I). Paris: OECD.

Pekrun, R., Goetz, T., Daniels, L., Stupnisky, R., \& Perry, R. (2010). Boredom in achievement settings: Exploring control-value antecedents and performance outcomes of a neglected emotion. Journal of Educational Psychology, 102, 531-549. http://dx.doi.org/10.1037/a0019243.

Pekrun, R., \& Linnenbrink-García, L. (2012). Academic emotions and student engagement. In S. Christenson, A. Reschly, \& C. Wylie (Eds.), Handbook of research on student engagement (pp. 259-282). New York, NY: Springer. http://dx.doi.org/10.1007/978-1-4614-2018-7_12.

Perry, R., Hladkyj, S., Pekrun, R., \& Pelletier, S. (2001). Academic control and action control in the achievement of college students: A longitudinal field study. Journal of Educational Psychology, 93, 776-789. http://dx.doi.org/10.1037/0022-0663.93.4.776.

Pianta, R., Hamre, B., \& Allen, J (2012). Teacher-student relationships and engagement: Conceptualizing, measuring, and improving the capacity of classroom interactions. In S. Christenson, A. Reschly, \& C. Wylie 
(Eds.), Handbook of research on student engagement (pp. 365-386). New York, NY: Springer. http://dx.doi.org/10.1007/978-1-4614-2018-7_17.

Pyryt, M. (2007). The giftedness/perfectionism connection: recent research and implications. Gifted Education International, 23, 273-279. http://dx.doi.org/10.1177/026142940702300308.

Raftery, J., Grolnick, W., \& Flamm, E. (2012). Families as facilitators of student engagement: Toward a home-school partnership model. In S. Christenson, A. Reschly, \& C. Wylie (Eds.), Handbook of research on student engagement (pp. 343-364). New York, NY: Springer. http://dx.doi.org/10.1007/978-1-4614-2018-7_16.

Reeve, J. (2012). A self-determination theory perspective on student engagement. In S. Christenson, A. Reschly, \& C. Wylie (Eds.), Handbook of research on student engagement (pp. 149-172). New York, NY: Springer. http://dx.doi.org/10.1007/978-1-4614-2018-7_7.

Reeve, J. \& Tseng, C. (2011). Agency as a fourth aspect of students' engagement during learning activities. Contemporary Educational Psychology, 36, 257-267. http://dx.doi.org/10.1037/a0028089

Roebers, C., Cimeli, P., Röthlisberber, M., \& Neuenschwander, R. (2012). Executive functioning, metacognition, and self-perceived competence in elementary school children: an explorative study on their interrelations and their role for school achievement. Metacognition and Learning, 7, 151-173. http://dx.doi.org/10.1007/s11409-012-9089-9.

Salanova, M., Martínez, I., Bresó, E., Llorens, S. \& Grau, R. (2005). Bienestar psicológico en estudiantes universitarios: facilitadores y obstaculizadores del desempeño académico. Anales de Psicología, 21, 170-180.

Salanova, M., Schaufeli, W., Martínez, I., \& Bresó, E. (2010). How obstacles and facilitators predict academic performance: The mediating role of study burnout and engagement. Anxiety, Stress \& Coping, 22, 1-18. http://dx.doi.org/10.1080/10615800802609965.

Sastre-Riva, S. (2013). High intellectual ability: Extracurricular enrichment and cognitive management. Journal of the Education of the Gifted, 36 (1), 119-132. http://dx.doi.org/10.1177/0162353212472407.

Skinner, E. (1996). A guide to constructs of control. Journal of Personality and Social Psychology, 71, 549-570. http://dx.doi.org/10.1037/00223514.71.3.549.

Skinner, E., Furrer, C., Marchand, G., \& Kinderman, T. (2008). Engagement and disaffection in the classroom: Part of a larger motivational dynamic? Journal of Educational Psychology, 100, 765-781. http://dx.doi.org/10.1037/a0028089.
Skinner, E., Kinderman, T., Connell, J., \& Wellborn, J. (2009a). Engagement and disaffection as organizational constructs in the dynamic of motivational development. In K. Wentzel \& A. Wigfield (Eds.), Handbook of motivation at school (pp. 223-245). London: Routledge.

Skinner, E., Kinderman, T., \& Furrer, C. (2009b). A motivational perspective on engagement and disaffection. Conceptualization and assessment of children's behavioral and emotional participation in the academic activities in the classroom. Educational and Psychological Measurement, 69, 493525. http://dx.doi.org/10.1177/0013164408323233.

Skinner, E. \& Pitzer, J. (2012). Developmental dynamics of student engagement, coping, and everyday resilience. In S. Christenson, A. Reschly, \& C. Wylie (Eds.), Handbook of research on student engagement (pp. 21-44). New York, NY: Springer. http://dx.doi.org/10.1007/978-1-4614-20187 .2.

Stoeber, J., Feast, A., \& Hayward, J. (2009). Self-oriented and socially oriented perfectionism: Differential relationships with intrinsic and extrinsic motivation and text anxiety. Personality and Individual Differences, 47, 423428. http://dx.doi.org/10.1016/j.paid.2009.04.014.

Stoeber, J., Hutchfield, J., \&Wood, K. (2008). Perfectionism, self-efficacy, and aspiration level: differential effects of perfectionistic striving and self-criticism after success and failure. Personality and Individual Differences, 45, 323-327. http://dx.doi.org/10.1016/j.paid.2008.04.021.

Stupnisky, R., Perry, R., Hall, N., \& Guay, F. (2012). Examining perceived control level and instability as predictors of first-year college students' academic achievement. Contemporary Educational Psychology, 37, 81-90. http://dx.doi.org/10.1016/j.cedpsych.2012.01.001.

Thompson, S., \& Schlehofer, M. (2008). The many sides of control motivation: Motives for high, low, and illusory control. In J. Shah \& W. Gardner (Eds.), Handbook of motivation science (pp. 41-56). New York, NY: Guilford Press

Tomarken, A., \& Waller, N. (2005). Structural equation modeling: Strengths, limitations, and misconceptions. Annual Review of Clinical Psychology, 1, 31-65. http://dx.doi.org/10.1146/annurev.clinpsy.1.102803.144239.

Wigfield, A., Tonks, S., \& Klauda, S. (2009). Expectancy-value theory. In K. Wentzel \& A. Wigfield (Eds.), Handbook of motivation at school (pp. 171195). London: Routledge.

Wu, A., \& Zumbo, B. (2008). Understanding and using mediators and moderators. Social Indicators Research, 87, 367-392. http://dx.doi.org/10.1007/s11205-007-9143-1.

(Article received: 17-06-2013; revised: 07-07-2014; accepted: 25-11-2014) 